\title{
Factors Affecting Profitability of Nepalese Non-Life Insurance Companies
}

\author{
Janga Bahadur Hamal*
}

DOI: https://doi.org/10.3126/jnbs.v13i1.34701

\begin{abstract}
The study examines the impacts of liquidity ratio, leverage ratio, firm size, age of the firm and total debt on the profitability of non-life insurance companies in Nepal. The dependent variable in the study is the return on asset (ROA), which is used as a measure of profitability. The study is based on secondary data of nine non-life insurance companies studied over a period of ten years, from 2066/67 to 2075/76. The data were collected from the financial statements published annually by the selected non-life insurance companies. Descriptive statistics, correlational analysis and regression models have been employed in order to test the impacts as well as the significance of the selected independent variables on ROA. The study concludes that the profitability of Nepalese non-life insurance companies increases with the increase in liquidity but decreases with the increase in leverage. However, the study establishes the insignificant relationship of firm size, firm age and total debt with profitability for the sector. The study thus suggests that non-life insurance companies should focus on the proper management of capabilities to pay liabilities to enhance profitability and also try to maintain a smaller value of leverage ratio to handle the above-average losses.
\end{abstract}

Keywords: Leverage, liquidity, non-life insurance companies, profitability

\section{INTRODUCTION}

Profitability is widely used to measure the performance of financial institutions all over the world. The importance of firm profitability can be appraised at the micro and macro levels of the economy (Bobakova, 2003). Sharma and Mani (2012) found that the

\footnotetext{
* Mr. Hamal is an Assistant Professor at Saraswati Multiple Campus, Tribhuvan University, Nepal. Email: janga.hamal@smc.tu.edu.np
} 
performance of firms is a major concern for economic planners and policymakers. The gain of the real sector economy depends upon how efficiently the firms are performing the function of financial intermediation. Insurance companies are widely known to provide unique financial services to the growth and development of every economy. They largely conduct activities that play a significant role in transferring risks, enhancing private investment, creating job opportunities and financing various developmental projects (Hofman, 2015). Despite the sector having eminent significance for the overall economy, the profitability of the global non-life insurance sector currently depicts a feeble trend (Swiss $\operatorname{Re}$ Institute, 2018).

The insurance sector plays a huge role in facilitating financial stability in an economy. In recent times, the interaction between various actors in the financial system-insurers, financial markets, banks and other intermediaries has been increasing. Additionally, these companies not only insure and safeguard the financial risk of houses and firms but also significantly contribute to the financial markets (European Central Bank, 2009). They thus become an important aspect of maintaining the financial stability of households, firms and the large number of investors who conduct transactions in the stock market. Consequently, earning profit has become a prerequisite for insurance companies. The sectors' profitability has been important for both micro and macro-level stability in the financial sector.

For the same reason, insurance companies are equally vulnerable to the smooth functioning of the financial system. The failure of one firm in the entire industry can cause financial turmoil in the economy. The major threat lies in the fact that such events have occurred from time to time (European Central Bank, 2009). With such a scenario it becomes imperative to analyze factors that determine profitability in non-life insurance companies, for, the financial performance of insurance companies has a larger effect on the economy. Many economists have thus been engraved with finding factors that determine the profitability of financial institutions. As per Batool and Shahi (2019), one of the major indicators of profitability is the return on asset (ROA). However, according to Kramaric et al. (2017), the early phases of such studies were conducted only in developed countries with a major focus on the banking sector. Gradually with time, numerous studies have been conducted in emerging markets that address the issue of determining the factors that affect the profitability of insurance companies.

A study on insurance companies of UAE conducted by Al-Shami (2008) included age, leverage, capital, loss ratio, and firm size as determinants of profitability. It revealed no relationship between profitability and the age of the company. It further concluded that firm size and capital have a significant and positive relationship with profitability. However, the study suggested a significant and negative relationship between leverage and loss ratio with profitability. A similar study was also conducted in Pakistan by (Ahmed et al., 2011). The ordinary least square regression results depicted significant and negative impacts of leverage and age on the profitability of the insurance firms. The indicator of having a significant and positive relationship with profitability was the firm size. Boadi et al. (2013) performed 
research to determine the factors affecting the profitability of insurance companies in Ghana. The study found a negative relationship of tangibility with profitability, but a positive relationship of leverage and liquidity with the profitability of insurance firms.

Gebremariyam (2014) suggested that insurance managers and policymakers should provide considerable focus on firm-specific factors to enhance its profitability. The study depicted that firm size, asset tangibility, firm growth and managerial efficiency are positively related to the profitability of insurance companies. On the contrary, leverage ratio and loss ratio/risk showcased a negative relation. Ngwili (2014) established a positive relationship between the quick ratio and profitability of insurance companies. The study further indicated a negative influence of leverage ratio and loss ratio on the profitability of insurance companies. A study conducted on the profitability of non-life insurance companies in Turkey depicted a positive relationship between firm size and profitability. However, the study found that the age of the firm is negatively related to its profitability (Kaya, 2015).

The results of the study conducted by Nyabate (2015) indicated that the relationship between liquidity and financial performance is positive but weak. However, the study concluded that liquidity is not the only contributor to profitability and other variables that exist. While at that, firms must take deliberate measures to optimize liquidity position. Berhe and Kaur (2017) in their research identified that firm-specific factors-size, capital, liquidity and growth rate - significantly affect the profitability as depicted by return on asset (ROA) of insurance companies in Ethiopia. On the contrary, factors like leverage ratio and loss ratio were found to have insignificant relations. Research by Kramaric et al. (2017) analyzed the influence of firm-specific variables, industry-specific variables and macroeconomic variables on profitability of the insurance market of central and eastern European countries revealed that size, age, combined ratio, share premium, and the real gross domestic product has a significant influence on return on equity of the companies, whereas, age of the firm was found to be the important factor as it depicted significant and positive relationship for both return on assets and return on equity of insurance companies.

Zainudin et al. (2018) conducted a study on firm-specific internal determinants of profitability performance in Asian countries - China, Hong Kong, Taiwan, Singapore, Japan, South Korea, Thailand and Malaysia. The study findings illustrated that size, capital and underwriting risk are significantly related to determining the ROA of Asian insurance companies. However, the model evinced an insignificant relation of premium, tangibility and liquidity. A study by Veronica and Ababio (2018) in Ghana disclosed that there is a positive and statistically significant relationship between profitability and debt. The study concluded that profitable insurance companies depend on long term debt. It also identified a positive relationship between profitability and the capital structure of the companies.

A recent study conducted in India by Hussanie and Joo (2019) revealed that liquidity, loss ratio, investment performance, operating margin, premium growth, and tangibility are 
significant in determining the profitability, as measured by ROA. On the other hand, leverage, commission ratio, and size are insignificant in explaining the profitability as measured by ROA. Investigations on the factors that determine the profitability of insurance companies have received much attention worldwide. However, as depicted by the aforementioned literature, there is no consensus on the determinants of profitability. The influencing factors are subject to change with the uniqueness of financial institutions in different countries.

In the context of Nepal, the role of non-life insurance companies is broad. Despite the sector still being in its infancy, its growth potential is huge (Sakhuja, 2003). According to Ghimire (2015), the substantial amount of funds generated through the industry if mobilized efficiently can have multifold positive effects for the overall economy. Thus, it is imperative to conduct ample research to prevent the failure of the companies operating in the insurance industry. For the same, it is necessary to analyze how insurance companies can amplify their profit. Poudel (2019) studied the effect of ownership as well as various firm-specific factors that determine the profitability of insurance companies. The study disclosed a negative relation of tangibility and liquidity with return on asset (ROA). Whereas, factors like firm size, age and leverage had a positive relation. Similarly, the study depicted a negative relationship between liquidity and return on equity and a positive relationship between firm size, age, leverage and tangibility. The regression analysis of the study identified firm size to be the most influential while determining the profitability of insurance companies.

However, the studies conducted to determine the factors that influence the profitability of non-life insurance companies is minimal in Nepal. The studies conducted have included very few variables affecting financial performance so far. This study is thus, conducted to identify the impacts of firm-specific variables on determining the profitability of non-life insurance companies in Nepal. In precise, it analyzes the relationship between liquidity, leverage, firm size, age of the firm and the total debt of the firm with its profitability, which is calculated in terms of return on assets (ROA). The study is divided into four sections. While the first section constituted of introduction and literature review, section two provides a brief explanation of the sample, data and methodology. In section three and four, empirical findings and the derived conclusion has been presented respectively.

\section{METHODOLOGY}

The pooled cross-sectional data analysis has been undertaken in the study, which was based on secondary data derived from annual reports of the selected companies. The population for the study was the number of listed non-life insurance companies in Nepal Stock Exchange Ltd. (NEPSE) by the end of Ashadh 2076, and there were 15 listed non-life insurance companies. The sample companies were selected based on the availability of complete information for the period of 10 years from 2066/67 to 2075/76. 
Table 1 illustrates the list of non-life insurance companies selected for the study. It also depicts the study period and the total number of observations made.

Table 1

Number of Non-Life Insurance Companies Selected for the Study Along with Study Period and Number of Observations

\begin{tabular}{clccc}
\hline S.N & Non-life insurance company & Symbol & Study period & Observation \\
\hline 1 & Everest Insurance Company Ltd & EIC & $2066 / 67-2075 / 76$ & 10 \\
2 & $\begin{array}{l}\text { Himalayan General Insurance Company } \\
\text { Ltd }\end{array}$ & HGI & $2066 / 67-2075 / 76$ & 10 \\
3 & Lumbini General Insurance Ltd & LGIL & $2066 / 67-2075 / 76$ & 10 \\
4 & Neco Insurance Company Ltd & NIL & $2066 / 67-2075 / 76$ & 10 \\
5 & Premier Insurance Company Ltd & PIC & $2066 / 67-2075 / 76$ & 10 \\
6 & Prudential Insurance Company Ltd & PICL & $2066 / 67-2075 / 76$ & 10 \\
7 & Sagarmatha Insurance Company Ltd & SIC & $2066 / 67-2075 / 76$ & 10 \\
8 & Shikhar Insurance Company Ltd & SICL & $2066 / 67-2075 / 76$ & 10 \\
9 & Siddhartha Insurance Ltd & SIL & $2066 / 67-2075 / 76$ & 10 \\
& & Total number of observations & 90 \\
\hline
\end{tabular}

The econometric models employed in this study analyzed the factors that affect profitability of non-life insurance companies in Nepal. The examinations performed were based on descriptive analysis, correlational and regression analysis.

\section{The Model}

The following regression model had been used in this study to examine the empirical effect of variables on the profitability of Nepalese non-life insurance companies.

$$
R O A=\beta_{0}+\beta_{1} A G E+\beta_{2} L I Q+\beta_{3} D E B T+\beta_{4} L E V+\beta_{5} S I Z E+\varepsilon
$$


Table 2

Variables and their Measurement Under the Study

\begin{tabular}{lcc}
\hline Variables & Notion & Expected priori sign \\
\hline $\begin{array}{l}\text { Return on assets (Net income divided } \\
\text { by total assets) }\end{array}$ & ROA & Dependent variable \\
Firm age & AGE & Positive \\
Liquidity & LIQ & Positive \\
Total debt & DEBT & Positive \\
Leverage & LEV & Negative \\
Firm size & SIZE & Positive \\
\hline
\end{tabular}

The following section describes the operational definition of independent variables used in this study.

Firm Age

The age of a firm can be defined as the number of years of incorporation of a company (Ilaboya \& Ohiokha, 2016). There have been many studies conducted to identify the impact of the age of the firm on the company's profitability. Many studies (Illaboya \& Ohiokha, 2016; Kramaric et al., 2017) confirm that firm age has a positive and significant relationship with its profitability. The study conducted by Poudel (2019) on insurance companies in Nepal also concluded that firm age has a positive influence on profitability. Henceforth, the following hypothesis has been developed for this study:

$H_{1}$ : There is a positive relationship between the age and profitability of non-life insurance companies in Nepal.

\section{Liquidity}

Liquidity is the degree to which an asset or security can be easily bought or sold in the market at its intrinsic value (Ghimire, 2013). In the case of insurance companies, liquidity refers to the capability of insurers to pay liabilities, including aspects like payment for operating expenses and payment for losses/benefits under insurance policies when due (Chen \& Wong, 2004; Boadi et al., 2013; Ngwili, 2014) established that there exists a positive relationship between liquidity ratio and profitability of insurance companies. Henceforth, the following hypothesis has been developed for this study:

$H_{2}$ : There is a positive relationship between the liquidity and profitability of non-life insurance companies in Nepal. 


\section{Total Debt}

Total debt is an indicator of capital structure of a company which can have several contradictory effect on its profitability (Muscettola \& Naccarato, 2016). A study concluded that profitable insurance companies depend on long term debt (Veronica \& Ababio, 2018). Henceforth, the following hypothesis has been developed for this study:

$H_{3}$ : There is a positive relationship between the total debt and profitability of non-life insurance companies in Nepal.

Leverage

Insurance leverage is determined by the ratio of premium to surplus and, thus, demonstrates the potential impact of deficiencies in premium due to the occurrence of unexpected losses of equity (Chen \& Wong, 2004). Many studies have concluded that the profitability and financial performance of firms are negatively influenced by their leverage (Kaya, 2015). Henceforth, the following hypothesis has been developed for this study:

$H_{4}$ : There is a negative relationship between the leverage and profitability of non-life insurance companies in Nepal.

Firm Size

The size of the company can be measured by many variables, but most studies use total assets to measure the size of the company (Omondi \& Muturi, 2013). Correspondingly, an increase in the total assets of non-life insurance companies increases the profitability of these companies in emerging markets. Studies performed considering this factor have also concluded that there is a positive relationship between the size of a company and the profitability of the company (Almajali et al., 2012). Henceforth, the following hypothesis has been developed for this study:

$H_{5}$ : There is a positive relationship between the size and profitability of non-life insurance companies in Nepal.

\section{RESULTS AND DISCUSSION}

\subsection{Descriptive Statistics of Dependent and Independent Variables}

Table 3 presents the descriptive statistics of dependent and independent variables from the data derived from ten selected non-life insurance companies during the period 2066/67 - 2075/76. 
Table 3

Descriptive Statistics for Selected Nepalese Non-Life Insurance Companies

The table shows the descriptive statistics of dependent and independent variables from the data derived from ten selected non-life insurance companies during the period 2066/67to 2075/76. The dependent variable is ROA (return on asset defined as net income divided by average total asset, in percentage). Similarly, the independent variables are, LIQ (liquidity defined as total assets divided by total current liabilities, in percentage), LEV (Leverage defined as the total liabilities divided by total assets, in percentage), DEBT (total debt defined as the sum of long-term and short-term debt of the firm, in million), SIZE (size defined as the total assets of the firm, in million) and AGE (age defined as the number of years the firm had operated during each fiscal year).

\begin{tabular}{ccccc}
\hline & Minimum & Maximum & Mean & Std. Deviation \\
\hline ROA & -0.09 & 1.23 & 0.1156 & 0.1635 \\
LIQ & 0.72 & 18.24 & 3.9184 & 3.2286 \\
LEV & 0.06 & 1.56 & 0.5151 & 0.3612 \\
DEBT & 16.88 & 672.64 & 225.7207 & 131.3735 \\
SIZE & 176.48 & 5199.36 & 1493.0171 & 1137.5743 \\
AGE & 4.00 & 25.00 & 16.1667 & 4.9747 \\
\hline
\end{tabular}

\subsection{Relationship between Dependent and Independent Variables}

Table 4 depicts the correlation coefficients of dependent and independent variables of none non-life insurance companies analyzed by the study. The table presents Pearson's correlation coefficient. The table illustrated a positive relationship between liquidity and profitability as measured by ROA which is similar to the findings of (Ngwili, 2014). It can be interpreted that the ability of insurance companies to pay liabilities has a positive effect on their profitability. This can be attributed to the fact that, when insurers are quick in paying their liabilities, it results in increased confidence of clients as well as shareholders. Similarly, the results showed a positive relationship of firm size with ROA and the result is consistent with (Almajali et al., 2012). Firm age also had a positive relationship with ROA of the company which is similar to the results of (Kripa \& Ajasllari, 2016). This means that the higher the size of the firm and the older the company, the ability to make more profit increases. However, the results are not statistically significant.

On the contrary, the results depicted a negative and statistically significant relationship between ROA and leverage of the firm and this result is consistent with (Kaya, 2015). The higher the leverage of the firm, the lesser will be its ability to make a profit and vice versa. The correlation analysis also showed a negative relationship between debt and ROA. This result is similar to that of (Jan et al., 2016). It means that, if insurance companies finance their expenses with higher debt, it can have a negative effect on their profitability. However, the result is not statistically significant. 
Table 4

\section{Pearson's Correlation Coefficient Matrix}

The following table depicts the bivariate Pearson's correlation coefficient between dependent and independent variables of selected non-life insurance companies operating in Nepal. It was analyzed with the data collected for the period of 2066/67 to 2075/76. The dependent variable is ROA (return on asset defined as net income divided by average total asset, in percentage). Similarly, the independent variables are, LIQ (liquidity defined as total assets divided by total current liabilities, in percentage), LEV (Leverage defined as the total liabilities divided by total assets, in percentage), DEBT (total debt defined as the sum of long-term and short-term debt of the firm, in million), SIZE (size defined as the total asset of the firm, in million) and AGE (age defined as the number of years the firm had operated during each fiscal year).

\begin{tabular}{ccccccc}
\hline & ROA & LIQ & LEV & DEBT & SIZE & AGE \\
\hline ROA & 1.000 & $.387^{* *}$ & $-.283^{* *}$ & -0.096 & 0.106 & 0.022 \\
LIQ & & 1.000 & $-.611^{* *}$ & $-.247^{* *}$ & $.411^{* *}$ & $.246^{* *}$ \\
LEV & & 1.000 & $.186^{*}$ & $-.468^{* *}$ & $-.364^{* *}$ \\
DEBT & & & 1.000 & $.549^{* *}$ & 0.129 \\
SIZE & & & & 1.000 & $.338^{* *}$ \\
AGE & & & & & 1.000
\end{tabular}

Note. The asterisk signs $(* *)$ and $(*)$ indicate that the results are significant at 1 percent and 5 percent level respectively.

It can be further analyzed that, liquidity despite having positive and statistically significant relation with ROA, its effect was found to be moderate. Since SIZE and AGE were positively correlated with the liquidity of the firm, it can indirectly contribute to the profitability of the firm. Similarly, SIZE and AGE had a negative relation with leverage. The higher the size and age of the firm, the lower will be the leverage. Consequently, the profitability can increase. However, leverage has a low negative relationship with ROA.

\subsection{Impact of Independent Variables on Return on Assets (ROA)}

This section presents the conclusions derived from a regression analysis. To be more concise, it represents the regression results of liquidity, leverage, total debt, firm size and age on ROA of non-life insurance companies in Nepal. Before running the regression analysis, multiple regression assumptions such as normality, multicollinearity, and independence of error were tested. 
Table 5

Estimated Regression Results of Liquidity, Leverage, Total Debt, Firm Size and Age On Return on Assets

The results have been derived from linear regression analysis of nine non-life insurance companies, studied over a period of ten years (2066/67 to 2075/76). The model is $R O A=\beta_{0}+\beta_{1} A G E+\beta_{2} L I Q$ $+\beta_{3} D E B T+\beta_{4} L E V+\beta_{5} S I Z E+\varepsilon$. Where, the dependent variable is ROA (return on asset defined as net income divided by average total asset, in percentage). Similarly, the independent variables are, LIQ (liquidity defined as total assets divided by total current liabilities, in percentage), LEV (Leverage defined as the total liabilities divided by total assets, in percentage), DEBT (total debt defined as the sum of long-term and short-term debt of the firm, in million), SIZE (size defined as the total asset of the firm, in million) and AGE (age defined as the number of years the firm had operated during each fiscal year).

\begin{tabular}{|c|c|c|c|c|c|c|c|c|c|}
\hline \multirow{2}{*}{ Models } & \multirow{2}{*}{ Intercept } & \multicolumn{5}{|c|}{ Regression coefficient of } & \multirow[t]{2}{*}{$\begin{array}{c}\text { Adjusted } \\
\mathrm{R}^{2} \\
\end{array}$} & \multirow[t]{2}{*}{ SEE } & \multirow[t]{2}{*}{ F-value } \\
\hline & & LIQ & LEV & DEBT & SIZE & AGE & & & \\
\hline 1 & $\begin{array}{l}0.039 \\
(1.538)\end{array}$ & $\begin{array}{l}0.020 \\
(3.936)^{* *}\end{array}$ & & & & & 0.140 & 0.152 & 15.49 \\
\hline 2 & $\begin{array}{l}0.182 \\
(6.244)^{* *}\end{array}$ & & $\begin{array}{l}-0.128 \\
(-2.765)^{* *}\end{array}$ & & & & 0.690 & 0.1577 & 7.646 \\
\hline 3 & $\begin{array}{l}0.65 \\
(1.276)\end{array}$ & $\begin{array}{l}0.342 \\
(2.42)^{* *}\end{array}$ & $\begin{array}{l}-0.074 \\
(-0.593)\end{array}$ & & & & 0.134 & 0.1522 & 7.865 \\
\hline 4 & $\begin{array}{l}0.064 \\
(1.068)\end{array}$ & $\begin{array}{l}0.17 \\
(2.689)^{* *}\end{array}$ & $\begin{array}{l}-0.034 \\
(-0.590)\end{array}$ & $\begin{array}{l}0.00 \\
(0.19)\end{array}$ & & & 0.124 & 0.153 & 5.183 \\
\hline 5 & $\begin{array}{l}0.193 \\
(4.042)^{* *}\end{array}$ & & $\begin{array}{l}-0.135 \\
(-2.569)^{* *}\end{array}$ & & $\begin{array}{l}0.00 \\
(-0.294)\end{array}$ & & 0.600 & 0.1585 & 3.827 \\
\hline 6 & $\begin{array}{l}0.143 \\
(2.25)^{*}\end{array}$ & & & $\begin{array}{l}0.00 \\
(-1.767)^{*}\end{array}$ & $\begin{array}{l}0.00 \\
(1.78)^{*}\end{array}$ & $\begin{array}{l}-0.01 \\
(-0.268)\end{array}$ & 0.013 & 1.382 & 0.182 \\
\hline 7 & $\begin{array}{l}0.239 \\
(3.243)^{* *}\end{array}$ & & $\begin{array}{l}-0.143 \\
(-2.88)^{* *}\end{array}$ & & & $\begin{array}{l}-0.03 \\
(-0.852)\end{array}$ & 0.067 & 0.158 & 0.019 \\
\hline 8 & $\begin{array}{l}0.056 \\
(0.852)\end{array}$ & $\begin{array}{l}0.024 \\
(3.414)^{* *}\end{array}$ & & $\begin{array}{l}0.00 \\
(0.636)\end{array}$ & $\begin{array}{l}0.00 \\
(-0.737)\end{array}$ & $\begin{array}{l}-0.002 \\
(-0.632)\end{array}$ & 0.122 & 0.153 & 4.079 \\
\hline 9 & $\begin{array}{l}0.128 \\
(1.58)\end{array}$ & $\begin{array}{l}0.022 \\
(3.05)^{* *}\end{array}$ & $\begin{array}{l}-0.092 \\
(-1.366)\end{array}$ & $\begin{array}{l}0.00 \\
(-1.36)\end{array}$ & $\begin{array}{l}0.003 \\
(-0.944)\end{array}$ & $\begin{array}{l}0.00 \\
(1.15)\end{array}$ & 0.130 & 0.152 & 3.669 \\
\hline
\end{tabular}

Note. Figures in parentheses are t-values. The asterisk signs $(* *)$ and $(*)$ indicate that the results are significant at 1 percent and 5 percent level respectively. The dependent variable is ROA.

The beta value presented in the second model of Table 5 showed that the most influential factor that has a significant impact on the profitability of non-life insurance companies is leverage. The adjusted $\mathrm{R}^{2}$ of 0.690 in the model showed that 69 percent of profitability can be explained by leverage. The finding depicted a negative and significant between leverage and profitability. This implied that higher leverage can jeopardize the 
profitability of non-life insurance companies in Nepal. The results are similar to the studies conducted by (Al-Shami, 2008; Boadi et al., 2013; Gebremaviram, 2014; Ngwili, 2014). This indicates that non-life insurance companies should be careful with their leverage ratio. The Fvalue of model five 3.827 is significant at a one percent level of confidence which shows that the model is fit. Likewise, the adjusted $\mathrm{R}^{2}$ value of 0.600 in model five illustrated that 60 percent of profitability can be explained by the variation in leverage and size of the firm.

The relationship between liquidity and ROA was found positive and statistically significant. The findings are consistent with (Ngwili, 2014; Boadi et al., 2013; Nyabate, 2015). This implies that liquidity has a positive influence in determining the profitability of non-life insurance companies operating in Nepal. Thus, investing in liquid assets to improve the liquidity can be deemed as helpful to enhance the profit ratio of insurance companies. The F-value of overall model 3.669 is also significant at a 1 percent level of confidence and indicates that the model is fit. Adjusted $\mathrm{R}^{2}$ of 0.13 implied that 13 percent of the ROA can be explained by the variations in the whole set of independent variables. Also depicted by the correlation analysis, the regression results depicted an insignificant relationship with size, age and debt of the non-life insurance companies with its profitability. The study conducted by (Hussaine \& Joo, 2019) also depicts an insignificant relationship between the size of the company and its profitability. Thus, debt has a negative, and size and age have a positive yet insignificant influence on determining the profitability of non-life insurance companies in Nepal.

\section{CONCLUSION}

Studies that aim to determine the profitability of non-life insurance companies is minimal or almost non-existent in Nepal. However, for maintaining the sound financial condition of the market, such studies are vital. Thus, this study aimed to investigate the impacts of liquidity ratio, leverage ratio, firm size, age of the firm and total debt of the firm on the profitability of non-life insurance companies in Nepal. The study is based on secondary data of nine non-life insurance companies for a period of ten years, that is, from 2066/67 to 2075/76. The results of the study conclude that the profitability of Nepalese non-life insurance companies increases with the increase in liquidity but decreases with the increase in leverage.

Nepalese non-life insurance companies, in order to enhance the profitability, should focus on the proper management of capabilities to pay liabilities. Similarly, the companies should try to maintain a smaller value of leverage ratio to handle the above-average losses. 


\section{REFERENCES}

Ahmed, N., Ahmed, Z., \& Usman, A. U. (2011). Determinants of performance: A case of life insurance sector of Pakistan. International Research Journal of Finance and Economics, 61, 123-128.

Almajali, A. Y., Alamro, S. A., \& Al-Soub, Y.Z. (2012). Factors affecting the financial performance of Jordanian Insurance Companies listed at Amman Stock Exchange. Journal of Management Research, 4(2), 266-289.

Al-Shami, H. A. (2008). Determinants of insurance company's profitability in UAE (Unpublished master's thesis). College of Business, University of Utara Malaysia.

Batool, A., \& Shahi, A. (2019). Determinants of financial performance of insurance companies of USA and UK during global financial crisis (2007-2016). International Journal of Accounting Research, 7(1), 194-218.

Berhe, T. A., \& Kaur, J. (2017). Determinants of insurance companies' profitability: Analysis of insurance sector in Ethiopia. International Journal of Research in Finance and Marketing, 7(4), 124-137.

Boadi, E. K., Antwi, S., \& Lartey, V. C. (2013). Determinants of profitability of insurance of insurance firms in Ghana. International Journal of Business and Social Research, 3(3), 43-50.

Bobakova, I. V. (2003). Factors affecting bank profitability. Journal of Banking and Finance, 3(11), 2080-2092.

Chen, R., \& Wong, K. A. (2004). The Determinants of financial health of Asian insurance companies. The Journal of Risk and Insurance, 71(3), 469-499.

European Central Bank (2009). Financial Stability Review. Retrieved from www.ecb.europa.eu.

Gebremariyam, M. M. (2014). Determinants of insurance companies' profitability in Ethiopia (Unpublished master's thesis). Addis Ababa University, Ethiopia.

Ghimire, R. (2013). Financial efficiency of non-life insurance industries in Nepal. Lumbini Journal of Business and Economics, 3(2), 1-14.

Ghimire, R. (2015). Life insurance companies in Nepal: A critical appraisal (Doctoral dissertation). Banaras Hindu University, India.

Hofman, D. M. (2015). Insurance - a global view: Markets, participants and challenges. Zurich Insurance Company Ltd.

Hussanie, I., \& Joo, B. A. (2019). Determinants of profitability of life insurers in India- panel evidence. International Journal of Management Studies, 6(1), 58-65.

Ilaboya, O. J., \& Ohiokha, I. F. (2016). Firm age, size and profitability dynamics: A test of learning by doing and structural inertia hypotheses. Business and Management Research, 5(1), 29-39. 
Jan, H. A., Khan, F., \& Muhammad, I. (2016). Impact of debt on profitability of firms: Evidence from non-financial sector of Pakistan. City University Research Journal, 8(1), 70-81.

Kaya, K. O. (2015). The effects of firm-specific factors on the profitability of non-life insurance companies in Turkey. International Journal of Financial Studies, 3(4), 120.

Kramaric, T. P., Miletic, M., \& Pavic, I. (2017). Profitability determinants of insurance markets in selected central and eastern European countries. International Journal of Economic Sciences, 6(2), 100-123.

Kripa, D., \& Ajasllari, D. (2016). Factors affecting the profitability of insurance companies in Albania. European Journal of Multidisciplinary Studies, 1(1), 352-360.

Muscettola, M., \& Naccarato, F. (2016). The casual relationship between debt and profitability: the case of Italy. Athens Journal of Business and Economics, 2(1), 1732.

Ngwili, K. P. (2014). The relationship between liquidity and profitability of insurance companies in Kenya (Unpublished master's thesis). University of Nairobi, Kenya.

Nyabate, O. J. (2015). Effect of liquidity on the financial performance of financial institutions listed in the Nairobi securities exchange (Unpublished master's thesis). University of Nairobi, Kenya.

Omondi, M. M., \& Muturi, W. (2013). Factors affecting the financial performance of listed companies at the Nairobi Securities Exchange in Kenya. Research Journal of Finance and Accounting, 4(15), 99-104.

Poudel, B. (2019). Impact of ownership structure on the profitability of Nepalese insurance companies. Nepalese Journal of Business, 6(3), 52-65.

Sakhuja, S. K. (2003, August). An untouched market for insurance. The Nepali Times. Retrieved from http://archive.nepalitimes.com/news.php?id=3785\#.XeIb4iN94nU.

Sharma, E., \& M. Mani (2012). Impact of macroeconomic and financial market indicators of the banking sector: Some evidence from India. International Journal of Research in Finance and Marketing, 2(2), 172-185.

Swiss Re Institue. (2019). World insurance: the great pivot east continues (3). Retrieved from www.swissre.com

Veronica, M., \& Ababio, C.K. (2018). The effect of capital structure on profitability of insurance companies in Ghana (Unpublished doctoral dissertation). Kwame Nkrumah University of Science and Technology, Ghana.

Zainudin, R., Mahdzan, N., \& Leong, E. S. (2018). Firm-specific internal determinants of profitability performance: An exploratory study of selected life insurance firms in Asia. Journal of Asia Business Studies, 12(4), 533-550. 